\title{
Internal Control, Nature of Equity and Corporate Social Responsibility
}

\section{---An Empirical Study Based on Main Board Listed Companies of Shanghai and Shenzhen Stock Exchanges}

\author{
$\mathrm{Lu} \mathrm{Sun}^{1} \&$ Nanni $\mathrm{Su}^{1}$ \\ ${ }^{1}$ School of Business, Sichuan University, Chengdu, China \\ Correspondence: Nanni Su, postgraduate student, School of Business, Sichuan University, Chengdu, China. \\ Received: December 16, 2017 \\ Accepted: January 10, $2018 \quad$ Online Published: January 31, 2018 \\ doi:10.5430/jms.v9n1p12 \\ URL: https://doi.org/10.5430/jms.v9n1p12
}

\begin{abstract}
Enterprises can promote the fulfillment of corporate social responsibility through excellent internal control so as to achieve the long-term development. Based on the empirical data of main board listed companies of Shanghai and Shenzhen Stock Exchanges from 2013 to 2015, this paper conducts an empirical test by establishing the relationship models among internal control, nature of equity and corporate social responsibility. The results indicate that: (a) Internal control can positively promote the fulfillment of corporate social responsibility; (b) The state-owned enterprises fulfill corporate social responsibility better than non-state-owned enterprises; (c) State-owned enterprises can enhance the positive effect of internal control on the fulfillment of corporate social responsibility.
\end{abstract}

Keywords: internal control, nature of equity, corporate social responsibility, state-owned enterprise

\section{Introduction}

Since the conception of corporate social responsibility was been put forward, scholars have tremendously studied it and formed richly and uniquely theoretical articles and empirical results. Meanwhile, with the rapidly economic development in our country and the constant progress of society, the issue of corporate social responsibility has gradually aroused the general public's attention. However, in recent years, the exposure of a great many scandals concerning food, medicine, environmental pollution and manufacturing defects had a big influence on society, which showed that to some extent the problem of the lack of corporate social responsibility was very serious. Therefore, this phenomenon aroused the close attention and extensive consideration about the issue of corporate social responsibility by scholars and the general public again. In this regard, "Company Law" article 5 clearly regulates: enterprises engaged in production and business activities must comply with relevant laws and regulations, accept supervision and undertake social responsibility. This mandatory regulation indicates the fulfillment of corporate social responsibility is an unquestionable topic but there are also a lot of efforts we need to do.

After the 2002 United States Sarbanes-Oxley Act, in order to strengthen and standardize enterprise internal control, China's Ministry of Finance and other five ministries successively promulgated the "Basic Norms for Enterprise Internal Control" and the "Guidelines for Supporting Internal Control" in 2008 and 2010. After that, scholars began to have a strong interest in discussing and studying internal control. Among these files, the "Enterprise Internal Control Application Guide No. 4 - Social Responsibility" document is the one attract my attention most. The document clearly stipulates that enterprises should incorporate corporate social responsibility into internal control in order to provide detailed guidelines for enterprises to use internal control to control social risks and promote corporate social responsibility. This event further indicates that enterprises need to undertake corporate social responsibility without any hesitation, and provides a new field scholars can research deeply-the relationship between internal control and corporate social responsibility.

Therefore, on the basis of theoretical research, this paper empirically tests the inner relationship between internal control and corporate social responsibility. Moreover, Shanghai and Shenzhen Stock Exchanges announced that they would classify the main board listed companies on January 1, 2012, and then implemented the "Guidelines for Supporting Internal Control" according to the classification. That is to say, state-owned listed companies needed to implement the guidelines in 2012, and non-state-owned listed companies and other listed companies in the main 
board implemented after 2012. It cannot help but give rise to a question. Is there any difference between state-owned and non-state-owned enterprises about the relationship of internal control and corporate social responsibility? So, this paper will further test the difference empirically, and hope to find another way to enhance corporate social responsibility through relevant research and expand a new understanding of internal control.

\section{Theoretical Analyses and Research Hypotheses}

\subsection{Internal Control and Corporate Social Responsibility}

By analyzing the problem of the lack of social responsibility such as Enron incident and China Sanlu milk powder incident, Rajagopalan \& Zhang (2009) put forward his own view on such issues: the reason leading to the lack of corporate social responsibility is the collapse of corporate governance structure. This view is consistent with Zhang, Zhao, \& Liu (2008). That is to say, corporate governance structure was the most important factor affecting the fulfillment of corporate social responsibility (Herman, 2012). Therefore, if enterprises wanted to achieve long-term and stable development, they must established a reliable corporate governance structure to prevent the lack of corporate social responsibility (Richard \& Dantel, 1999) and solidified corporate social responsibility as an inherent system (Lu, 2002). According to COSO (The Committee of Sponsoring Organizations of the Treadway Commission), the essence of internal control was the risk management process of corporate governance structure. Automatically, internal control was the most important part in corporate governance structure (Yi, 2012). So, the improvement of corporate governance structure depended on the improvement of internal control (Cohen et al., 2010). Based on the above content, corporate governance structure has created a good environment for the fulfillment of corporate social responsibility, and internal control, as the institutional basis of corporate governance, was the direct factor that acted on the fulfillment of corporate social responsibility $(\mathrm{Li}, 2014)$. In addition, other relevant literature studied internal control and corporate social responsibility also directly showed: the reason that the lack of corporate social responsibility was the failure of internal control or unreasonable design (Qi \& Shang, 2015; Sun, Dong, \& Wang, 2016; Chen \& Liu, 2017). While exposing major deficiencies in internal control, it also reflected the weak awareness of management on social responsibility. Meanwhile, internal control lacked systematicness and effectiveness would result in every aspect of corporate social responsibility be under lower supervision and restriction (Wang, Liu, \& Han, 2015). So far, it is clear that internal control is always an important factor affecting the lack of corporate social responsibility no matter from what aspects of any research.

As mentioned earlier, China's Ministry of Finance and other five ministries promulgated "Enterprise Internal Control Application Guide No.4 - Social Responsibility". This document, for the first time, integrates internal control and corporate social responsibility with a view to enhancing the fulfillment of social responsibilities by strengthening internal control of enterprises. Wang, Wu, \& $\mathrm{Li}$ (2011) also indicated a significant function of enterprise internal control was to supervise and control the fulfillment of social responsibilities and strive to balance the interests of various stakeholders. Wang \& Shen (2012) and Sun et al., (2016) demonstrated that the effectiveness of internal control was a guarantee of fulfillment of corporate social responsibility, and nowadays, social responsibility has been embedded into the whole process of internal control. Feng \& Zhou (2015) further pointed out that the higher the quality of the implementation of internal control system, the higher the strategic management level, this situation meant a better level of the fulfillment of corporate social responsibility. Moreover, many other scholars elaborated the influential path of internal control on corporate social responsibility by thoroughly analyzing the objectives and elements of internal control as indicated in the relevant documents. For instance, Li (2014) and Zhang \& Wang (2016) asserted, firstly, the control environment, as one of the control elements, inherently contained ingredients such as values that positively promote the fulfillment of social responsibilities; Secondly, internal control's objective system contained the pursuit of corporate social responsibility; In addiction, internal control as a risk management system could greatly reduce the probability of adverse events affecting corporate social responsibility, which could further improve the fulfillment of social responsibilities. Based on the above content, this paper proposes hypothesis 1:

H1: Internal control can positively promote the fulfillment of corporate social responsibility.

\subsection{Internal Control, Nature of Equity and Corporate Social Responsibility}

Feng, Lin, \& Xu, (2011) proved empirically that state-owned listed companies are more inclined to fulfill corporate social responsibility than non-state-owned listed companies. This conclusion is consisted with Cui \& Liu (2009). Since state-owned enterprises can be regarded as tools and means by which the government participate and intervene in the economy, the government's thoughts and benefits determine the behaviors of state-owned enterprises, therefore, state-owned enterprises can adjust the economic situation during their daily operations. In other words, state-owned enterprises are more inclined to implement some socially beneficial things, such as fulfilling more social responsibilities. Huang \& Yu (2006) also analyzed that the social responsibility of state-owned enterprises included 
economic goals and non-economic goals. Specifically, state-owned enterprises' social responsibility was to focus more on the realization of non-economic goals, and the realization of economic goals was to serve for the realization of non-economic goals. In short words, state-owned enterprises needed to make greater contribution to our society than non-state-owned enterprises. Therefore, authors assert that state-owned enterprises can better fulfill their social responsibilities compared with non-state-owned enterprises.

Li (2014) thoroughly analyzed the impact of the nature of equity in the promotion of corporate social responsibility on internal control, which provided us profound inspiration. He thought that state-owned enterprises were subject to many mandatory policies and laws concerning social responsibility, which prompting them to establish a sound internal control system, and they needed to constantly improve it to meet relevant requirements. Notably, the continuous improvement of the internal control system could create a better corporate governance environment for state-owned enterprises, and the fulfillment of social responsibilities depended on this. However, non-state-owned enterprises had a low awareness of social responsibility, so they did not have the mandatory motivation to fulfill their social responsibilities at most of the time, but just followed the leaders' wishes or the industries and social requirements they were in. And their internal control environments were poor, which limits the promotion of internal control in the performance of corporate social responsibility. Indeed, in the context of China's special system, state-owned enterprises have received more attention and are under greater pressure from internal and external surroundings, which is to raise their internal control levels so as to promote the fulfillment of social responsibilities. In addition, the reason why Shanghai and Shenzhen Stock Exchanges classified the main board listed companies and then implemented the "Guidelines for Supporting Internal Control" respectively is based on the actual situation of corporate governance. This shows the internal control level of state-owned enterprises is higher than that of non-state-owned enterprises and can further promote the positive impact on the fulfillment of social responsibilities.

Therefore, authors have reasons to believe that the internal control of state-owned enterprises to promote social responsibility is greater than non-state-owned enterprises. Based on the above content, this paper proposes the following hypothesis 2 and hypothesis 3 :

H2: Compared with non-state-owned enterprises, state-owned enterprises can better fulfill their corporate social responsibility.

H3: Compared with non-state-owned enterprises, state-owned enterprises can enhance the positive effect of internal control on the fulfillment of corporate social responsibility.

\section{Research Design}

\subsection{Sample Selection and Data Sources}

This paper selects main board listed companies of Shanghai and Shenzhen Stock Exchanges during 2013-2015 years as research samples and filters the data according the following conditions: (a) remove the financial and insurance listed companies; (b) remove all listed companies remarked ST or *ST; (c) remove the missing data companies. Finally, there are 1423 data samples obtained. All the financial data in this paper come from CSMAR, the all internal control indexes are obtained from Dibo Internal Control and Risk Management Database (DIB), the corporate social responsibility scores come from Rankins CSR Ratings Company (RSK). In this paper, authors use Excel software and SPSS 23.0 software to process all related data.

\subsection{Variable Definition}

\subsubsection{Corporate Social Responsibility (CSR)}

First, as a famous third-party rating agency of corporate social responsibility, Rankins CSR Ratings Company evaluates social responsibility very carefully and thoroughly, so its result is very objective and authoritative. Seccond, according to a large amount of former literature, such as Tang (2016), author finds that RSK's result has generally accepted. So, this paper chooses it to evaluate corporate social responsibility.

\subsubsection{Internal Control (IC)}

First, Dibo Internal Control Index (DIB) is the first one to reflect all Chinese listed companies' internal control level and risk management capacity. The evaluation system is comprehensive, the result is authoritative which with a high degree of identity. Second, according to the research of Wang et al., (2015) and other relevant literature, this paper chooses DIB as the variables to measure internal control.

\subsubsection{Nature of Equity (GQ)}

This paper defines state-owned enterprises as 1 and non-state-owned enterprises as 0 . 


\subsubsection{Control Variables}

A large number of existing literatures have pointed out that: enterprise's scale and financial leverage can affect the promotion of internal control on corporate social responsibility (Qi, 2015; Chen \& Liu, 2017; Feng et al., 2011). So, this paper chooses enterprise's scale and financial leverage as control variables. Table 1 demonstrates the all definitions.

Table 1. Definitions of variables

\begin{tabular}{cccc}
\hline Variable type & Variable name & Variable sign & Calculation method \\
\hline Dependent variable & $\begin{array}{c}\text { corporate social } \\
\text { responsibility }\end{array}$ & CSR & RSK \\
\cline { 2 - 4 } Independent variable & Internal control & IC & DIB \\
\cline { 2 - 4 } Control variable & Nature of equity & GQ & $\begin{array}{c}1 \text { for state-owned } \\
0 \text { for } \\
\text { non-state-owned }\end{array}$ \\
\cline { 2 - 4 } & Enterprise's scale & SIZE & $\begin{array}{c}\text { The natural logarithm } \\
\text { of total assets }\end{array}$ \\
\cline { 2 - 4 } & Financial leverage & LEV & Debt asset ratio \\
\hline
\end{tabular}

\subsection{Model Designs}

According to the former theoretical analysis and refer to the research about Tang (2016), Wang et al., (2015) and Li (2014), this paper designs three models to study relevant hypotheses.

$$
\begin{gathered}
C S R=\alpha 0+\alpha 1 I C+\alpha 2 S I Z E+\alpha 3 L E V+\varepsilon \\
C S R=\beta 0+\beta 1 G Q+\beta 2 S I Z E+\beta 3 L E V+\varepsilon \\
C S R=\gamma 0+\gamma 1 I C+\gamma 2 I C * G Q+\gamma 3 S I Z E+\gamma 4 L E V+\varepsilon
\end{gathered}
$$

To be specific, the model 1 is used to test hypothesis 1 that internal control can positively promote the fulfillment of corporate social responsibility; the model 2 is used to test hypothesis 2 that state-owned enterprises can better fulfill their corporate social responsibility compared with non-state-owned enterprises; the model 3 is used to test hypothesis 3 that state-owned enterprises can enhance the positive effect of internal control on the fulfillment of corporate social responsibility compared with non-state-owned enterprises.

\section{Empirical Results and Analyses}

\subsection{Descriptive Analysis}

Table 2 depicts the descriptive statistics of the major variables. We can find that the maximum CSR is 87.95 and the minimum is 18.27 during the sample years. It is shows that Chinese main board listed companies' performance of CSR varies greatly, and the average value 41.6 further demonstrates that there is still much room for improvement in social responsibility. Moreover, there is a large gap between the maximum IC of 908 and the minimum of 264, indicating that the level of internal control is quite different. But the average value 667 shows the overall situation is good.

Table 2. Descriptive statistics of the major variables

\begin{tabular}{llllll}
\hline Variable & Sample & Minimum & Maximum & Average & $\begin{array}{l}\text { Standard } \\
\text { Deviation }\end{array}$ \\
\hline CSR & 1423 & 18.27 & 87.95 & 41.60 & 12.06 \\
\hline IC & 1423 & 264.51 & 908.38 & 667.73 & 86.97 \\
\hline LEV & 1423 & 0.06 & 1.11 & 0.53 & 0.19 \\
\hline SIZE & 1423 & 19.55 & 28.51 & 23.38 & 1.39 \\
\hline
\end{tabular}

\subsection{Correlation Analysis}

Table 3 shows the result of Pearson correlation analysis among the variables. We can find that the correlation 
coefficient between CSR and IC is 0.19 and is significant at the 5\% level, which tentatively support the hypothesis 1 . The correlation coefficient between CSR and SC is 0.21 and is also significant at $5 \%$, so we can tentatively trust the hypothesis 2. The correlation coefficient between the number of IC multiply GQ and CSR is 0.23 and is significant at the level of 5\%, which testify the hypothesis 3 now.

Table 3. Pearson analysis

\begin{tabular}{lllllll}
\hline & CSR & IC & GQ & IC*GQ & LEV & SIZE \\
\hline CSR & 1 & & & & & \\
\hline IC & $0.19 * *$ & 1 & & & & \\
\hline GQ & $0.21 * *$ & 0.02 & 1 & & & \\
\hline IC GQ $^{*}$ & $0.24 * *$ & $0.24 * *$ & $0.97 * *$ & 1 & & \\
\hline LEV & $0.07 * *$ & 0.00 & $0.06 * *$ & $0.07 * *$ & 1 & \\
\hline SIZE & $0.40^{* *}$ & $0.12 * *$ & $0.14 * *$ & $0.17 *$ & $0.45^{* *}$ & 1 \\
\hline
\end{tabular}

Note: * indicates significant correlation at $10 \%$ level (bilateral levels); ** indicates significant correlation at $5 \%$ level (bilateral levels); $* * *$ indicates significant correlation at $1 \%$ level (bilateral levels).

\subsection{Regression Analysis}

Table 4 below shows the regression results of models 1, 2 and 3. By observing the regression result of model 1, we can find that CSR and IC are significantly and positively correlated at the level of 5\%, which strongly testifies the hypothesis 1 . So, indeed, there is a positive relationship between internal control and corporate social responsibility, and internal control can positively promote the fulfillment of corporate social responsibility. The regression result of model 2 indicates corporate social responsibility (CSR) and nature of equity (GQ) also have a significantly positive correlation of 5\% level, so we can trust the hypothesis 2 that state-owned enterprises have fulfilled their corporate social responsibilities better than non-stated-owned enterprises. The complex model 3 has a clear result that CSR not only significantly and positively correlate to IC, but also with IC*GQ at the level of 5\%. This is a strong evidence can be used to trust hypothesis 3 . Therefore, state-owned listed companies can indeed enhance the positive effect of internal control on the fulfillment of corporate social responsibility. In addition, the two control variables, enterprise's scale (SIZE) and financial leverage (LEV), are positively correlate with corporate social responsibility in every model, this is consist with former literature. Moreover, every DW value is about 2, depicting there is no sequence autocorrelation among the data.

Table 4. Regression analysis

\begin{tabular}{|c|c|c|c|}
\hline & Model 1 & Model 2 & Model 3 \\
\hline & Coefficient & Coefficient & Coefficient \\
\hline & (T-value) & (T-value) & (T-value) \\
\hline \multirow{2}{*}{$\mathrm{IC}$} & $0.14 * *$ & & $0.11 * *$ \\
\hline & 5.93 & & 4.43 \\
\hline \multirow{2}{*}{ GQ } & & $0.16^{* *}$ & \\
\hline & & 6.50 & \\
\hline \multirow{2}{*}{$\mathrm{IC} * \mathrm{GQ}$} & & & $0.16^{* *}$ \\
\hline & & & 6.33 \\
\hline \multirow{2}{*}{ LEV } & $-0.13 * *$ & $-0.14 * *$ & $-0.13^{* *}$ \\
\hline & -4.82 & -5.15 & -4.89 \\
\hline \multirow{2}{*}{ SIZE } & $0.44 * *$ & $0.44 * *$ & $0.42 * *$ \\
\hline & 16.46 & 16.42 & 15.72 \\
\hline F-value & 115.15 & 118.04 & 98.78 \\
\hline $\mathrm{DW}$ & 2.07 & 2.07 & 2.07 \\
\hline Adj-R ${ }^{2}$ & 0.19 & 0.20 & 0.22 \\
\hline $\mathrm{N}$ & 1423 & 1423 & 1423 \\
\hline
\end{tabular}

Note: * indicates significant correlation at $10 \%$ level (bilateral levels); ** indicates significant correlation at $5 \%$ level (bilateral levels); *** indicates significant correlation at $1 \%$ level (bilateral levels). 


\section{Research Conclusions and Enlightenment}

Based on the research analysis and theoretical discussion, this paper puts forward three hypotheses about internal control, nature of equity and corporate social responsibility, then choose the data of main board listed companies in Shanghai and Shenzhen Stock Exchanges during 2013-2015 years to conduct the empirically study.

The conclusions of this study are as follows: (a) Internal control can positively promote the fulfillment of corporate social responsibility; (b) After classifying the samples, compared with non-state-owned enterprises, state-owned enterprises fulfill their social responsibilities to a greater extent; (c) By adding the item of IC multiply GQ, we find that state-owned enterprises can enhance the positive effect of internal control on the fulfillment of social responsibilities. In other words, in state-owned enterprises, internal control is more effective in promoting social responsibility.

From the conclusions of the study, we can obtain some enlightenment. Due to the importance of social responsibility is self-evident nowadays and it is related to the long-term and stable development of enterprises, it is necessary for enterprises to promote the fulfillment of corporate social responsibilities by establishing a sound and reasonable internal control system. Non-state-owned enterprises are not subject to mandatory requirements and pressure from the outside surroundings like state-owned enterprises in many ways, which leads to a lower fulfillment of corporate social responsibility than state-owned enterprises. However, non-state-owned enterprises should pay attention to speeding up the pace of internal control design or perfection, and strive to reduce the risk of corporate governance through good internal control system as soon as possible, so as to enhance their performance of social responsibility and achieve better self-competitiveness.

To sum up, regardless of state-owned or non-state-owned enterprises, internal control is always an important way to enhance the fulfillment level of corporate social responsibility.

\section{References}

Chen, H. M., \& Liu, X. T. (2017). The empirical study among internal control, corporate social responsibility and financial performance-Based on the pharmaceutical manufacturing industry. Journal of Changsha University of Science \& Technology (Social Science), (2), 97-102.

Cohen, J., G. Krishnamoorthy., \& A, Wright. (2010). Corporate governance in Post-Sarbanes-Oxley era: Auditors' experiences. Contemporary Accounting Research, 27(3), 751-786. https://doi.org/10.1111/j.1911-3846.2010.01026.x

Cui, X. M., \& Liu, J. (2009). Market-oriented Process, Ultimate Controlling Personality and Corporate Social Responsibility-Empirical Evidence from Listed Companies in Shanghai, China. Soft Science, (1), 30-38.

F, L. L., Lin, F., \& Xu, J. L., (2011). Property Ownership, Ownership Concentration and Corporate Social Responsibility Performance. Journal of Shanxi University of Finance and Economics, (9), 100-107.

Feng, L. L., \& Zhou, Wen. J. (2015). Can the Execution of Internal Control Promote the Fulfillment of Corporate Social Responsibility? A Paired Research Based on No.4 Application Guidelines-Social Responsibility for Enterprise Internal Control. Journal of Nanjing Audit University, (3), 99-112.

Herman, A., \& Ante, G. (2012). What we know and don't know about corporate social responsibility: A review. Journal of Management, (4).

Huang, S. J., \& Yu, J. (2006). The Nature, Objectives and Social Responsibility of State-owned Enterprises. China Industrial Economy, (2), 68-76.

Li, Z. B. (2014). Internal Control, Nature of Actual Controller and Corporate Social Responsibility-Empirical Evidence from Chinese Listed Companies. Economic Survey, 31(5), 109-114.

Lu, D. F. (2002). Economic and Legal Analysis of Corporate Social Responsibility. Beijing, Law Press.

Qi, P., \& Shang, L. (2015). Research on Internal Control Based on Corporate Social Responsibility. Enterprise Economy, 12(4), 45-48.

Rajagopalan, N., \& Zhang. Y. (2009). Recurring failures in corporate governance: A global disease? Business Horizons, 52(6), 545-552. https://doi.org/10.1016/j.bushor.2009.06.007

Richard, A, J., \& Dantel, W. G. (1999). The effects of corporate governance and institutional ownership types on corporate social performance. Academy of Management Journal, 42(5), 564-576. https://doi.org/10.2307/256977 
Sun, F. C., Dong, Q., \& Wang, H. B. (2016). Corporate Social Responsibility Internal Control: Review and Outlook. Friends of Accounting, (3), 32-36.

Tang, X. J. (2016). Internal Control, Institutional Environment and Disclosure Quality of Corporate Social Responsibility. Journal of Accounting and Economics, (2), 85-104.

Wang, H. B., Liu, S., \& Han, B. (2015). The Effect of Internal Control and Financial Performance on Corporate Social Responsibility-An Empirical Analysis Based on Listed Companies of A-share. Taxation and Economy, (6), 1-9.

Wang, H. B., Wu, Z. X., \& Li, W. J. (2011). Humanism Interpretation and Framework Reconstruction of Enterprise Internal Control. Accounting Research, (7), 59-65.

Wang, J. C., \& Shen, X. Q. (2012). Corporate Social Responsibility and Internal Control: Interactive Relationship and Optimization Path Research. Communication of Finance and Accounting, (9), 13-15.

Yang, X. S. (2005). An Empirical Study on the Relation between Cost Strategic Management and Sustainable Developing of Listed Companies. Accounting Research, (7). 49-54.

Yi, K. G. (2012). Study on the Multiple Values Game and Long-term Mechanism of Corporate Social Responsibility-A Perspective of the Corporate Governance. Economic Theory and Business Management, (12), 61-67.

Zhang, L. T., \& Wang, J. L. (2016). Does Internal Control Quality Influence Corporate Social Responsibility Level. Journal of Northwest University (Philosophy and Social Sciences Edition), (5), 55-62.

Zhang, Z. G., Zhao, S. W., \& Liu, X. X. (2008). New Development of Corporate Governance: Corporate Social Responsibility. Wuhan University Journal (Philosophy\& Social Sciences), (5), 631-635. 